\title{
Europe's Responses to Fukushima: Nuclear Renaissance Revisited?
}

\author{
BARTHÉLÉMY COURMONT ${ }^{*}$
}

The accident at the Fukushima nuclear plant on March 2011 has had a major effect on the public perception of nuclear energy worldwide. In Europe, its psychological impact has been particularly strong, as it happened exactly twenty-five years after the Chernobyl nuclear accident of 1986 . On a continent where the highest number of nuclear plants is concentrated, it has led several countries, including Germany, to call for a phase-out, while other nuclear powers, such as France and the United Kingdom, have kept their nuclear policies unchanged, and reaffirmed their projects to build new plants. These profound divisions among European countries raise the question of whether the "nuclear renaissance" will be revisited. This article examines the media reactions to the Fukushima accident in several European countries, and the political decisions that followed, in order to evaluate the European responses to Fukushima. It focuses on the different perceptions and their direct effects on the political decisions taken in European countries.

Keywords: Fukushima, Europe, Nuclear Energy, Nuclear Renaissance, Stress-Tests

\footnotetext{
* Professor at the Political Science Department at Hallym University (Chuncheon, Republic of Korea), and Associate-research fellow at the Paris-based Institute of International and Strategic relations (IRIS). $\mathrm{He}$ is also Chief editor of the French quarterly Monde chinois, nouvelle Asie.
} 


\section{INTRODUCTION}

$\mathrm{T}$

he Fukushima nuclear incident consequent to the earthquake followed by a tsunami that ravaged Japan's east coast on March 11, 2011, not only raised the question of nuclear safety, but also appears more globally as a potential major threat to the so-called "nuclear renaissance" (Richburg 2011). This direct consequence of the Japanese catastrophe has been particularly visible in Europe, where it coincided with the twenty-fifth anniversary of the nuclear meltdown at Chernobyl. Fukushima has already reignited almost dormant public fears about nuclear safety (IISS 2011). It has incited heated discussions about the desirability of nuclear power. By awakening fears that still appear to be very strong within the public's opinion, this debate threatens to halt what had seemed too much like a budding nuclear renaissance, a term used to refer to a possible nuclear power industry revival, driven by rising fossil fuel prices and new concerns about meeting greenhouse gas emission limits. In the past few years, this new trend has been welcomed by the major nuclear energy producers in Europe, and at the same time vividly criticized by the opponents of nuclear energy, indicating the deep divergences among European public opinion, and by extension opposing pro- and anti-nuclear countries. The opposition has been increasing after 2009, when Sweden announced its intention to construct new nuclear power plants, reversing its 30-year nuclear phase-out policy, and even more in 2010, when Germany announced the extension of its nuclear plants. In several European countries nuclear power has been making a comeback under the pretence of protecting the climate. For instance, the Estonian daily newspaper Eesti Päevaleht lamented:

The key argument with which these states are trying to make their nuclear plans socially acceptable is climate protection. Nuclear power plants emit no greenhouse gases. That means there is no need to pay good money for CO2 emission rights, which make power from fossil fuels even more expensive. But the loud majority is not always right. Calculations by the International Energy Agency show that if you want to reduce greenhouse gases, building nuclear power plants is far less effective than other measures. Better results can be obtained by developing renewable energy, as well as introducing energy-efficient measures in industry, traffic and households. At the same time possibilities for storing renewable energy must be looked into. The problem with wind energy, for example, is that the wind does not keep blowing all the time. (Kaljuvee 2010).

Although Estonia is neither a major European nuclear power, nor in a position where it can influence the nuclear policies of countries such as Germany or France, this posture is indicative as it reflects the position of various European non-governmental movements opposed to nuclear energy prior to the Fukushima accident, and it also indicates the difficulties these movements have met in 
order to influence the decision-makers in the past two decades.

More generally, considering how important nuclear energy has become in the last quarter of a century in Europe, the aftermath of the Fukushima accident might indeed be much deeper than it was after Chernobyl. The coverage of the Japanese catastrophe by the European media and the spectacular decisions taken by some European countries tend to confirm this situation. For many observers, Fukushima marked the "end of nuclear" more than Chernobyl ever did, mostly because it took place in a very advanced country (Reuters 2011). There has been a big change in attitudes as a response to Fukushima as powerful as there was to the 1986 Chernobyl disaster, according to Xavier Rabilloud of the French green movement "Sortir du Nucléaire" (Get out of Nuclear): "The fact that so many countries have demanded that reactors should undergo stress tests is a clear admission that safety of nuclear power is an illusion and that no one can guarantee that nuclear accidents will never happen" (Manac'h 2011).

Officially, the World Nuclear Association still mentions a global nuclear renaissance, despite Fukushima (World Nuclear Association 2011). It still states that atomic power can help meet increasing global energy demand, fight climate change and reduce reliance on imported energy (Herbst and Hopley 2007; Ferguson 2007; Cravens 2007). It also argues that nuclear power reactors account for far less greenhouse gases than fossil fuel plants over their lifetimes. In Europe, most states tend to act in accordance to this line, with the exception of Germany, Austria and Belgium. While Greenpeace insists 68 percent of EU electricity needs to come from renewables by 2030 and 99.5 percent by 2050 , nuclear output still has priority. However, Europe's divisions over nuclear power have deepened since Fukushima, with Britain and France remaining steadfast supporters, Italy shelving plans to build new plants (after abandoning it in 1987) but facing a massive disapproval by Parliament, and Germany calling for a phase-out after Chancellor Angela Merkel called the Fukushima accident a "turning point in the history of the industrial world" (The Economist 2011a).

The revision of the nuclear renaissance accelerated by the divergences among the member states, and particularly the German U-Turn (considering that Germany is the strongest economy within the EU, but also the most populated member state), has potentially important consequences in a continent where nuclear energy has been particularly successful (Boyd 2011). In the past decades, the EU countries have been considered world leaders in the field of nuclear energy, largely due to the lack of natural resources that convinced several states to adopt a pro-nuclear policy. All together, 14 member states out of 27 produce nuclear energy. The biggest producers are France, with 5 reactors in operation and another 2 planned, the UK with 19 currently in use and another 8 to come on-stream, and Germany currently with 17 reactors. The others are Sweden (with 10), Spain (8), Belgium (7), the Czech Republic (6), Finland (4), Hungary (4), Slovakia (4), Bulgaria 
(2), Romania (2), the Netherlands (1), and Slovenia (1). Besides the EU, Switzerland, whose government recommends phasing out by 2034, has 5 reactors; Russia has 32 and there are 15 in Ukraine. Another is currently under construction in Belarus. Considering the importance of nuclear energy at the continental level, decisions taken by some countries to phase-out, therefore, have an impact that appears more important in Europe than in other regions. It also determines the legacy of the nuclear renaissance and serves as a test to evaluate public support for nuclear energy, and therefore the future of the nuclear renaissance.

This article studies the European reactions to the Fukushima disaster and the divergences in nuclear policies that have been implemented by member states since. After focusing on the media's reaction, it will analyze the political responses, comparing the German approach with the Franco-British pro-nuclear position, before concluding the effects of these divergences at the EU level.

\section{THE MEDIA REACTION TO THE NUCLEAR ACCIDENT: AN INDICATOR OF EUROPEAN DIVERGENCE}

Whatever the ultimate scale of the nuclear accident underway at the Fukushima plant in Japan, the ground in Europe has been trembling as never before since Chernobyl in 1986 (Kitschelt 1986; Rüdig 1990). In all different European countries, the media reported the comparison between the two events, and echoed the differences in responses to the catastrophe among the European countries, a reminder of the differences also clearly occurred back in 1986. Initially the mainstream media paraded a stream of anti-nuclear activists who excelled in predicting an equivalent of Armageddon with cataclysmic consequences (Voskimovich 2012), notably by comparing Fukushima with Chernobyl and with a strong impact on public opinion. "The debate that seemed to be fading away with the memory of Chernobyl has come back with brutal insistence," noted Le Figaro (Nodé-Langlois 2011). The French daily newspaper explained that what was happening in Japan was dealing "an extremely hard blow to the side of the nuclear power sector globally." It came following soaring oil prices in 2008 that "permitted talk of a resurgence in nuclear power for civilian use around the world," and the desire of "Brussels, urged on by Paris, to rank nuclear power among 'carbon-free energy sources,' such as hydroelectric, solar or wind power." "In no region of the world is nuclear energy as important as it is in Europe," underlined the German Die Welt (2011), to indicate that changes in this field would have more impact if they were initiated in Europe than in any other part of the world.

Today, however, wrote Le Figaro, "those opposed to nuclear power are regaining strength throughout Europe. In Germany, where the conservative-liberal government of Angela Merkel voted in the autumn of 2009 to extend the shelf-life 
of the country's 17 nuclear reactors; $\cdots$ in Austria, a country traditionally hostile to nuclear energy, whose environment minister, Nikolaus Berlakovich, has pleaded for a 'stress test' for European plants; $\cdots$ in Britain, where the Cameron government has revived its plant construction program and in October identified eight new sites, the energy minister, Chris Huhne, has said he supports an investigation 'to learn the necessary lessons' from the event, while the government will decide in June whether to authorize use of the EPR (European Pressurized Reactor) technology from Areva and EDF" (Nodé-Langlois 2011).

The shock has been strong enough to bring us to "the end of the nuclear era," Der Spiegel headlined (Der Spiegel 2011). Representing the public's fears, the German weekly magazine demanded that the doctrine of zero risk be immediately revisited: "Certainly, Japan is an earthquake zone, which increases the risk there and is one distinction between Japan and Germany or France. But Japan also has among the most highly developed industries, in which well-trained and punctilious engineers build the most modern and most reliable cars in the world. At the time of the disaster in Chernobyl, the German nuclear industry was able to persuade itself and the German public that in Eastern Europe the reactors were outdated and the engineers were incompetent and negligent. We see now just how presumptuous this perception was. $\cdots$ All we need is a series of unfortunate accidents [and] Fukushima would be in everyone's back yard" (Der Spiegel 2011).

The risks regarding a potential "European Fukushima" quickly focused on the central and eastern nuclear plants, a move already observed after Chernobyl in 1986, when the safety of the eastern block nuclear facilities had been strongly, and legitimately, questioned. For years, reports the Austrian newspaper Der Standard, "Doubts have been voiced about the safety of Eastern European plants such as those at Mochovce [Slovakia] and Temelín [Czech Republic, near the Austrian border]. When it comes to power in Germany, though, the criticism is more muted. As it happens, for example, we've known for years that the Neckarwestheim plant in Baden-Wurttemberg is in a seismic zone." This vulnerability reminds us that "nuclear issues haven't yet come up with clear answers: Is the technology controllable? Can the plants be made safer? Can safe disposal of waste be guaranteed? It's up to the EU to launch inspections of all nuclear installations in Europe," maintains the paper, which considers the proposals of the Austrian Minister of Environment, Nikolaus Berlakovich, to conduct stress tests for nuclear power plants to be a "step in the right direction" (Der Standard 2011).

Since 1979, when radiation leaked from the Three Mile Island plant in the United States, "we have made great technological strides forward," the Czech newspaper Hospodářské noviny pointed out (Novak 2011). Unlike in 1986, the date of the Chernobyl disaster, "there is no longer any communist regime that as a matter of principle cares not a whit for the safety of its people," and 
most of Europe does not lie within a seismically active region. For that reason, "to abandon nuclear power would be even more absurd, given that alternative energy sources are limited. The proper response to Fukushima is not to dump nuclear energy in a panic, but to draw the right conclusions from what happened and improve safety measures" (Novak 2011). In other words, the EU must act as a responsible power, and address the potential risks if it does not want to be exposed to a major public disapproval of nuclear energy.

Because of its impact and its potential consequences on the European nuclear energy programs, the Fukushima accident should certainly not be underestimated, wrote Sergio Rizzo in an editorial in the Italian newspaper Corriere della Sera. On the other hand, "the emotion understandably caused by this tragedy should not determine our fundamental energy policy choices. We've done it already and we burned our fingers: the [Italian] anti-nuclear referendum of 1987 was passed by a large majority because of the shock over the accident at Chernobyl" (Rizzo 2011). But instead of leading to such promised green energy, the vote that approved shutting down Italian nuclear plants has led instead to a new dependence on oil. In the past two years, Italy has been a good example of a state tempted by a nuclear renaissance. A confidence vote in 2011 allowed the Berlusconi cabinet to launch a new program of the construction of nuclear plants.

The most radical position was taken by Belgium's De Standaard: "We have to pay the price for our way of life," since "as we are not prepared to radically curtail our consumption, we must accept that electricity at affordable prices comes with some risks." It is in this context that, by coincidence, the Belgian authorities launched a campaign to "inform the public on possible protective measures in the event of nuclear accidents" (De Standaard 2011).

It is hard to evaluate whether the media had succumbed to hysteria and amplified the opposition to nuclear energy because of public opinion by mentioning Chernobyl, or simply revealed and reactivated a fear with regard to nuclear energy among the European population. Some experts criticized "sensationalism" in the media coverage of the nuclear accident, while most anti-nuclear groups organized protests and public demonstrations in order to force governments to take immediate and radical action. Throughout Europe, especially in countries such as Germany, Italy, Spain and Sweden, anti-nuclear protesters took the Fukushima accident and the media coverage as an opportunity to call for an immediate phase-out.

The media undoubtedly revealed the impact that public opinion may have on leaders, depending on the national culture and perception of nuclear energy in different EU states. In the coverage of the accident, the media also illustrated the gap between the sometimes excessive and irrational responses, and the political consequences of the nuclear accident, which show deep differences as well, and therefore may be separated into three different groups. According to Vojin 
Joskimovich, "Media and stock market hysteria belonged in the first group. Responses of the German government, the Swiss cabinet and the Italian Council of Ministers represent the second group. The third group with rational responses is represented by political leaders in key nuclear countries" (Joskimovich 2012). In this respect, the examples of France and Germany are particularly relevant, as they incarnate the two opposite directions taken by governments after the Fukushima accident, the "second" and "third" groups, according to Joskimovich's description.

\section{THE SPECTACULAR GERMAN U-TURN}

Angela Merkel's decision to extend the working life of Germany's 17 nuclear plants in 2012, reversing a deal done ten years ago between the SPD-Green government and the energy producers for an exit by 2021, was considered the most significant proof of a nuclear renaissance in Europe. For the same reason, the spectacular German U-Turn appears to be the proof of its necessary revision.

A few weeks after the Fukushima accident, Angela Merkel announced that the seven power stations built before 1980 would be closed provisionally. Germany already had suspended a decision to maintain production at other nuclear plants built in the 1980s and 1990s. As Mycle Schneider stated, "In record time, what once was the most pro-nuclear German government in decades prepared comprehensive legislation to phase out the remaining nine reactors by 2022 at the latest, starting in 2015" (Schneider 2011).

After Merkel took over in 2005 as leader of a coalition with the Social Democrats, she quietly reversed plans to phase out nuclear power taken by the Social Democrats-the Green coalition that had led the country since 1998 (Schneider et al. 2009). This U-Turn in German nuclear policy is quite radical, but does not appear to be a major surprise considering the recent history of this country. The meltdown of a Soviet reactor in Chernobyl in 1986 caused such hysteria in Germany that the nuclear industry has never recovered, despite the fact that fears of radioactive clouds proved greatly exaggerated. Since then, political leaders have been constantly fighting with a massive anti-nuclear movement that has never faded, and strongly opposed recent decisions to renew the German nuclear plants.

The costs of the reactor accident in Fukushima will also be substantial, and European countries believe that these costs will be a burden for the Japanese economy for years, if not decades. These economic costs will be an additional factor leading to a rethink of the nuclear energy. There are already signs that this is happening, especially in Europe. Until recently, it would have been impossible to subject all nuclear power plants within the EU to a European stress test based on a uniform standard, as the European Council, partly in response to 
pressure from the German government, has decided after Fukushima. Germany will also push for a new international assessment of the risks of nuclear energy at a special conference in 2012 of the signatory countries of the Convention on Nuclear Safety. Last, Berlin intends to promote renewable energy as a response to the risks posed by nuclear plants.

"Germany must speed up its transition to renewable energy in the wake of the Fukushima nuclear accident," wrote Norbert Röttgen, the German environment minister, in an opinion article published in Der Spiegel on April 24, 2011. He believes Germany can lead the way with a successful shift into green power that will boost its economy in the long term.

Germany marked a drastic policy reversal by announcing on May $30^{\text {th }}$ that it will shut all its nuclear reactors by 2022, after an agreement within the coalition parties, and only three days after a severe defeat of Merkel's party, the $\mathrm{CDU}$, in an important election in the southern state of Baden-Württemberg (The Guardian 2011). Angela Merkel backtracked in March 2011 on an unpopular decision just months earlier to extend the life of ageing nuclear stations in Germany, where the majority of voters oppose atomic energy. In June 2011, the Bundestag voted 513-79 to completely shut down all of the country's nuclear plants by 2022, approving Merkel's decision. The legislative package included seven other laws that go from energy efficiency ( $€ 3$ billion per year for buildings alone) to renewable energy (the target is now for a 35 percent share of electricity by 2020) to new gas power plants, and on to massive expansion of the power distribution system (Schneider 2011). Germany currently receives 23 percent of its power from nuclear plants.

The consequences of the Fukushima accident went beyond Merkel's decision in Germany, and extended to German politics. In a historic March election in Bade-Wurttemberg, the Green Party doubled its votes to reach 24.2 percent and trailed only the formerly governing Christian Democratic Union. For the first time, a Green prime minister leads a coalition government (with the Social Democrats) in the third largest German state, which has a population of more than 10 million.

For some observers, the German U-Turn reflects the weak state of Merkel's government, which is criticized on various issues and has been facing difficulties in local elections. But considering the importance of Germany within the EU, the decision to quit nuclear power undoubtedly has major effects on the other European countries' positions. The EU Energy Commissioner Guenther Oettinger told Germany's ARD Television: "When a large member state like Germany re-examines atomic energy this can have consequences at the European level. If we in Germany are examining nuclear plants from the 80s and 90s, we must also raise the question of whether the security check should be done for all atomic plants in Europe." The cost of such a decision might be, in the short-term, extremely high for the German economy. According to some analysts 
Germany will become a net importer of about 4 terawatt hours of power by the end of the year following a reported export of 14 terawatt hours for the previous year as a result of nuclear policy change (Brown 2011). Germany could employ euro reserves to obtain electricity from neighboring countries to reconcile energy deficits in transitioning the world's fourth largest economy to alternative non-nuclear energy solutions. The Dena Energy Agency, a research institute partly owned by the German government, has estimated that Germany will have to spend nearly $\$ 14.3$ billion over the next decade to upgrade its electrical grid if the country is to stop using neighboring networks. Considering the economic and financial difficulties the euro-zone countries are currently facing, does that mean that Germany could reconsider its costly decision? Certainly not in the short-term, but it would be premature to believe that Germany has definitely given up its nuclear energy, and will never reconsider its choice.

Following Germany's footsteps, Austria called for all nuclear reactors in Europe to undergo stress tests in the event of severe earthquakes. Switzerland said it had suspended plans to renew nuclear power plants (Kanter 2011). However, "Germany, Switzerland, and Italy decided to abandon their nuclear industries while reeling from having recently witnessed the greatest nuclear disaster in a generation. It is not inconceivable that they would reconsider the timelines for phase-out as they begin to feel the full economic impact of these dramatic policy shifts" (Ergo 2011).

Within the EU, Germany and Austria have pushed for stress tests to be carried out on all of Europe's reactors to ensure that they could stand up to earthquake and tsunami scenarios such as that which occurred at the Fukushima plant. The issue is hot also in Spain, where solar energy is the most important renewable source, in Belgium, and in Scotland, a state-less energy fulcrum that is home to about a quarter of Britain's nuclear capacity, but whose new and separatist majority government does not want any new reactor.

In Italy, a referendum had been on the table since 2008 to open a number of nuclear plants that were shuttered after Chernobyl. As soon as the Fukushima accident occurred, the referendum was dead on arrival. The proposal was finally rejected in June 2011 by 95 percent of voters, which forced the then Prime Minister Silvio Berlusconi to admit that "we shall probably have to say goodbye to nuclear [energy]" (Galiay 2011). While support for the referendum was already waning due to its support from an unpopular Silvio Berlusconi (who eventually resigned a few months later in November 2011), experts agreed that Fukushima was responsible for the lopsided margin. "I think there is now less than 0.01 percent chance for nuclear [energy] in Italy," commented Luigi De Paoli, energy economy professor, at the Bocconi University in Milan (Cooke 2011).

These examples raise not only the question of a possible radical change in the EU energy policy, but also the particularity of some European countries in a situation comparable to the Fukushima accident. One may admit that 
the spectacular decisions taken by countries such as Germany and Austria and, to a certain level, Belgium, were made possible by the presence, within the EU, of important nuclear energy producers such as France, that will be the optional source during the period of time required to develop renewable energy. Such radical decisions would certainly have been further debated in other circumstances. Other nuclear energy producers in various regions, notably in Northeast Asia, do not have such an option. The case of Japan is particularly sensitive in this prospect. Although the Fukushima accident has had, for obvious reasons, a deep impact on the public's perception of nuclear energy, Japan cannot give up its nuclear policy without exposing its energy dependence, as it would need to import fossil energy, and does not benefit from the reserves of an ally in its vicinity, sharing strategic and economic interests, as well as a common currency. In that sense, because it unites nuclear energy producers and their consumers, the EU case is a unique one, the governments' margin being far more limited in other regions.

\section{PARIS' AND LONDON'S NUCLEAR RESISTANCE}

Among the European countries that took totally different paths than Germany, France and the UK appear as leaders, since these two countries vigorously defended nuclear energy as the only relevant alternative to fossil fuels. Among the arguments quoted in these countries, the difficulty to develop renewable energy without facing major consequences has been one of the most important, several leaders arguing that "we cannot switch to renewables overnight" (Bloomberg 2011). However, debates whether nuclear energy is still the most relevant option took place in these countries, following the German decision.

France is by far Europe's biggest producer of atomic energy (and second biggest globally after the United States). Due to its lack of natural resources, it is also the most nuclear-dependant country in the world. Some $80 \%$ of energy consumed in the country comes from nuclear sources. Unsurprisingly for a country that relies so heavily on the atomic energy sector, the reaction to the Japanese dilemma was muted at first. French Environment Minister Nathalie KosciuskoMorizet initially called the nuclear accident in Japan "extremely serious," but added that "France should not follow the rest of the EU in overreacting to the situation domestically" (Le Parisien 2011a). However, her tone was significantly more alarmist two days later. On her way to an emergency cabinet meeting, Kosciusko-Morizet said Japan was heading for "catastrophe." She said that the concrete vessel around the reactor was leading to "the worst scenario" (Le Parisien 2011c).

After this statement, France's political and nuclear leaders have repeated and emphasized the difference between France and Japan, mostly in order to respond 
to the public's fears. In an interview with Le Parisien a few days after the tsunami, Anne Lauvergeon, CEO of French nuclear energy giant Areva said that while the world was analyzing the lessons coming out of Japan, the situation in France posed very different challenges. "There is no risk in France of a tsunami hitting our power stations nor is there a risk of such powerful earthquakes," she said. Responding to calls from environmentalists to halt nuclear energy production, she replied: "They are surfing a wave of emotion. The reality of nuclear energy is that it produces no $\mathrm{CO} 2$, electricity is 40 percent cheaper in France than in the rest of Europe" (Le Parisien 2011b).

The presidential election held in April-May 2012 that led to the victory of the Socialist candidate François Hollande and the electoral campaign pushed the ecologist movement to call for the abandonment of nuclear dependence for the future. Although the Green Party has been advocating a different energy policy for France in the past decades, this position was mostly justified by an Ifop (French Institute of Public Opinion) opinion poll published on June 4, 2011. It found just over three-quarters of those surveyed wanted a gradual withdrawal from nuclear technology in the next 25 to 30 years. In that poll, only 22 percent of respondents supported building new nuclear power stations, 15 percent backed a swift decommissioning and 62 percent a gradual one. In other words, 77 percent of respondents expressed support for a nuclear phase-out (Le Journal du Dimanche 2011). Anticipating such results, the Green Party made nuclear energy a critical issue prior to the 2012 election. Eva Joly, candidate of the Green Party, believed that although France could not give up its nuclear potential in the near future, considering its importance, political measures had to be taken to focus on renewable energy. According to her party, a referendum must be held on nuclear energy in the near future. The Green Party even made the nuclear issue a condition to a possible alliance with the socialist party, on the eve of the 2012 presidential election. In April 2011, a study by UBS predicted that around 30 nuclear plants may be closed worldwide as a result, with those located in seismic zones or close to national boundaries being the most likely to shut. The UBS analysts believe that "even pro-nuclear counties such as France will be forced to close at least two reactors to demonstrate political action and restore the public acceptability of nuclear power," noting that the events at Fukushima "cast doubt on the idea that even an advanced economy can master nuclear safety" (Les Echos 2011).

The exigency from the ecological party divided the candidates for the socialist primaries, which designated the party's candidate to the 2012 presidential election in an October 2011 vote. Martine Aubry, secretary-general of the Socialist party, praised Angela Merkel's decision and believes that France should strongly consider a nuclear-end strategy within twenty to thirty years. But she refused to define any agenda. Ségolène Royal shares this approach, considering that forty years seems more reasonable. Arnaud Montebourg has been more cautious and believes 
that any debate regarding the future of energy in France should invite the industries, including the major nuclear companies. Less radical and known for his "pro-nuclear" position, François Hollande suggests a transition in order to reduce the nuclear dependence, but refuses to consider that France will dismantle all of its nuclear plants within half a century. The former secretary-general of the party calls for a reduction from 75 percent to 50 percent of the electricity provided by nuclear within a few decades. Hollande's success in the Primaries (and a few months later in the election, with 51.6 percent of the vote in the second round against Nicolas Sarkozy) did not close the debate however, as a clear deal has not been reached with the Green Party (whose candidate, Eva Joly, had only 2.1 percent of voters in the election's first round), although both parties came to a series of agreements, notably in order to prepare the legislative election.

François Hollande announced his decision to close the oldest French nuclear plant, in Fessenheim (Alsace, north-east of France, near the German and Swiss borders), asserting that this plant is outdated and built on a seismic zone. This decision, taken prior to his election, has been criticized by his rival Nicolas Sarkozy, who accused the Socialists for making concessions with the green party on France's nuclear energy capabilities. The newly elected president does not, however, have any plan other than closing the Fessenheim plant, which appears therefore to be a highly symbolic gesture more than a potential change of France's nuclear policy. But he will have to take into account a growing debate regarding the possible orientations of France's energy policy and its nuclear capabilities, as several reports from the Union Française de l'Electricité (UFE) and the think tank Global Chance have already raised the question of the viability of a phase-out strategy (UFE 2011; Dessus 2011). The scenarios of nuclear energy representing 70 percent of the electric production (as stated in the Grenelle Agreement, 50 percent and only 20 percent have been explored, and the new president will have to clarify his position, especially considering the economic impact) (Lévêque 2012).

During the presidential campaign, debates regarding the future of nuclear energy were not however limited to the Green and Socialist parties. The center-right former minister of ecology, Jean-Louis Borloo, stated that France has developed renewable energy considerably in the past few years, in comparison to the other EU countries. He noted that such efforts would be enhanced by the Fukushima accident. Although he was not a candidate for the presidential election, his position had a significant impact on the positions defended by the center voters, who represented merely 10 percent of the voters, but also on Sarkozy's supporters in the center, who favor a two-track posture based on a backup of nuclear energy and a stronger support for renewable energy.

The UMP (Nicolas Sarkozy's party) approach was more pragmatic, the former presidential party believing that France and Germany, the closest allies in the 
EU, came to a compromise on Germany's abandonment of its nuclear capabilities. In public, President Sarkozy and Chancellor Merkel were diametrically opposed on the nuclear power issue. But in reality, her decision to get out of the nuclear power business means that France will be supplying a growing proportion of German energy needs over coming decades. As The Economist pointed out two weeks after the accident, "the French nuclear industry may even see Fukushima as an opportunity. The EPR is touted as being especially safe: if concerns about safety could be turned into a regulatory case for building only EPRs in Europe, so much the better" (The Economist 2011b). Already dominant in Europe's energy field, France could improve its status after both the abandonment of nuclear policies in some member states who will become energy importers, as well as the implementation of more strict regulations, that favor the advanced French nuclear energy industry. Nicolas Sarkozy himself stated on June $7^{\text {th }}$ that "If they (the Germans) stop their reactors, then they will have to be replaced. We'll be candidates to sell electricity." (Ouest France 2011). Somehow, Merkel's recent decision has been more welcomed by the French government than the one she took in 2010, when she decided to expand the life of the German nuclear reactors. In this prospect, it is likely that the Socialist government led by François Hollande will adopt a pragmatic approach similar to Sarkozy's position, and "be candidate to sell electricity" to Germany.

Alongside France, the United Kingdom also vigorously defended its atomic energy program. British Energy Minister Chris Huhne said that plans to build eight new nuclear power stations in England and Wales would go ahead. While saying that the British energy sector would "learn every possible lesson" from the Japanese crisis, he told the BBC that "there is a very big difference in that we're, frankly, amazingly lucky that we don't live in a seismically active earthquake zone like Japan." But the British government is facing a growing opposition from Scotland, and its new pro-independence government, which announced its desire to close down the nuclear reactors built in the Scottish territory.

Among the other EU members, the Czech Republic, as an important uranium producer, stands behind the position defended by France and the UK. Other countries such as Finland, Slovakia or Hungary, also rejected any revision of their nuclear policy in the near future. But in these countries, like in France or in the UK, the elections could have an impact on future decisions.

\section{THE EFFECTS AT THE EU LEVEL: FROM POLITCAL FRICTIONS TO NECESSARY AGREEMENTS}

The Fukushima accident revealed the difficulties for the EU countries to find agreement and address a coherent common policy on issues as sensitive as nuclear 
energy and safety (Bryant 2011). The biggest problem is that the EU does not have a policy on nuclear energy since the issue falls under national jurisdiction. "You have so very different approaches on nuclear energy across different member states of Europe" (MacIsaac 2011), said Arthur Runge-Metzger, director of the European Union Directorate A "Internal and Climate Strategy," at a climate change conference in New York in late September 2011. "You have France, which is highly powered by nuclear energy on one side. Just across the Rhine, you have Germany that wants to get as fast as possible out of nuclear energy," he added (MacIsaac 2011). Although they abandoned their borders, share the same currency, constantly work on common approaches in dealing with economic, social and legal problems, the EU members still remain totally independent and separated from each other when it comes to energy policies.

The issue of renewable energy is also central in EU divergences. In 2010, the European Climate Foundation (ECF) published a much-noted report called "Roadmap 2050," which modeled in great detail the cost and technical feasibility of various scenarios for a carbon-free power system in Europe by 2050 (European Climate Foundation 2010). It describes a scenario of 80 percent renewable power, complemented by a remnant of nuclear and fossil fuels with carbon capture and sequestration. The ECF's conclusion is that a continent-wide renewable power system is both technically possible and economically affordable. The much-maligned and very real intermittency of supplies of renewable power is addressed through additional back-up generation capacity and, crucially, a new direct-current super-grid that enables load balancing across the European continent. But the ECF fails in responding to the critical question of alternatives between the end of nuclear power and the rise of renewable power. This uncertainty leads the European nuclear powers such as France in a position where it is extremely unlikely that they will follow the German example, and explains the strong divergences in the responses to the Fukushima accident. In France, besides the Green Party, there is no significant movement that advocates a phase-out, and the legitimate emotions consequent to the Fukushima accident, reported in the media and through some opinion polls, does not reveal a major shift of public opinion on nuclear energy.

\section{European Countries' Nuclear Capacities and Recent Developments}

GERMANY: The government voted in 2010 to extend the lives of Germany's 17 nuclear plants. But after the Japanese nuclear disaster, Germany reversed course, saying it would move out of nuclear power, keeping shut 8 suspended reactors and closing the rest by 2022 . Of the 17 in total, another 6 will be taken offline by 2021, Environment Minister Norbert Roettgen said. As of January 2011, Germany's capacity was 20,490 MWe.

FRANCE: France is building a 1,600 MW reactor at Flamanville, which is expected to begin 
commercial operation in 2014, two years later than originally planned. France currently has 58 nuclear plants with a capacity of 63,130 MWe, making it the second nuclear energy producing country in the world after the United States, but by far the first in terms of percentage of electricity produced from nuclear power.

UNITED KINGDOM: Europe's leading utilities have bought land to build new nuclear power plants in England and Wales, with the first expected to be built by 2018. As of January 2011, Britain had 19 nuclear power plants with a capacity of 10,137 MWe.

SWEDEN: Sweden has 10 nuclear plants with a capacity of 9,303 MWe, and supplies around 50 percent of the country's electricity.

ITALY: The only non-nuclear G8 industrialized nation, Italy decided in 1987 to shut its reactors following the Chernobyl disaster in Ukraine. Italy's centre-right government won a confidence vote in May 2011 on a package of measures that included shelving plans to build new nuclear power plants. Prime Minister Silvio Berlusconi decided to scrap the construction of new nuclear plants amid mounting public concern, but a massive disapproval vote in the Parliament in June 2011 jeopardized his nuclear ambitions.

BELGIUM: After a governmental decision in 2003 to close the 7 national nuclear reactors (located in two plants, in Tihange and Doel) between 2015 and 2025 (when they will reach their 40 years of activity), the Herman Von Rompuy government decided in 2009 to extend the plants existence for ten more years. In the current negotiations to form a new government, the decision to phase-out after 2015 has been adopted, confirming the 2003 strategy, and following in Germany's footsteps.

CZECH REPUBLIC: Czech utility CEZ postponed a tender to add two more units at its Temelin nuclear power plant in 2010 due to uncertainty in power markets, now expected in 2013. The Czech Republic has 6 plants with a capacity of 3,722 MWe.

FINLAND: The parliament voted to build two new nuclear reactors in July 2010. It is building a fifth nuclear reactor, the 1,600-megawatt Olkiluoto-3, expected to come online in 2013 after several delays. Finland has 4 plants with a net capacity of 2,716 MWe.

NETHERLANDS: Dutch utility Delta plans to build a nuclear plant with EDF that could be operational by 2019. The Netherlands has 1 nuclear plant with a capacity of 487 MWe. POLAND: The government wants 1 or 2 nuclear power plants of its own to be built, the first by 2022 , to break its reliance on coal for energy. The project already has been delayed once from 2020.

SLOVAKIA: Two 470-MW units are being built at Mochovce and expected to operate from 2012-2013 in a project led by Enel unit Slovenske Elektrarne. Slovakia has 4 nuclear plants with a capacity of 1,792 MWe.

As soon as the media reported the Fukushima accident, strong opposition started to occur among EU members. The divergence took another step when the EU Energy commissioner (from Germany) Günther Oettinger described the Japanese nuclear crisis as "an apocalypse," comments which caused financial markets to plunge and hit Japan's economy as it struggled to cope with a devastating earthquake. At an emergency Brussels meeting called by the German commissioner to discuss new tests of Europe's reactors, Eric Besson, the French energy minister, accused Mr Oettinger of "neurotic" opposition to atomic power. This type of vivid criticism is a good indication of how Germany upset several 
EU members with its decision, and how it rapidly reached the EU institutions. More than the choices made by various EU members regarding their nuclear policy, the frictions quickly focused on the necessity to implement stress tests in order to secure EU nuclear capabilities.

The scope of the tests is still the subject of controversy, however. Oettinger is pushing for simulated responses to terror attacks and plane crashes to be undertaken as part of the exercise, while regulators from the nuclear nations want to limit them to natural disasters. "These tests should be comprehensive and include the widest range of scenarios, natural and man-made, focusing on their possible impact on the plants' functioning systems," the EU Commission President Jose Manuel Barroso said on May 11 ${ }^{\text {th }}, 2011$ (L'usine nouvelle 2011). It shows clearly the interaction between nuclear safety and nuclear security, both for public opinion and political leaders (Findlay 2010). For several experts, however, the EU Commission should draw a realistic EU-wide nuclear phase-out plan, within the horizon of fifty years, and throw it down the pipes of the EU decision-making process. Even if it were to be rejected, it would still trigger crucial debates, as important as those on the euro, which ended up being a success praised by member states themselves (Galiay 2011).

An agreement was finally reached. Government ministers and officials from nearly thirty nuclear energy producing countries were called upon on June $7^{\text {th }}$ for safety tests on all reactors, after the disaster at Fukushima plant sparked concern over standards. In addition to finding a consensus on stress tests of nuclear safety, the ministers and officials also agreed on the need to reinforce the IAEA's role on nuclear safety. "The Fukushima accident in Japan shook us all and the need arose very quickly to draw lessons, to improve and lift our standards and cooperation on nuclear safety," French Environment Minister Nathalie Kosciusko-Morizet said after the conference she chaired. She was followed by German Deputy Environment Minister Ursula Heinen-Esser, who stated that "Stress test or resilience tests are a first priority to identify vulnerabilities." As a result, "the decisions made by the majority of European countries over the past five months suggest that a strengthened industry is emerging, with tougher regulations and stricter adherence to industry best practices for safety and efficiency" (Ergo 2011).

The European countries also proved their ability to reach a common policy and set an example to the nuclear countries in the rest of the world. The EU was able to bring nuclear safety onto the agenda of the United Nations General Assembly in New York in September 2011, which has been seen as a sign of strong European unity, particularly welcomed after several months of divisions. It also revealed the capacity of the EU members to go beyond their divergences on nuclear policies to adopt a common approach on safety issues. The aftermath of the Fukushima nuclear accident have been particularly important in Europe, and have showed the lack of dialogue in addressing a common nuclear policy. 
It also served as an interesting indicator of the necessity for the EU members to reach agreements in order to respond to the crisis.

Against the backdrop of economic and financial crises with deep social consequences, the EU also chose to focus on alternatives to nuclear energy in the long term, through a study released in January 2012, entitled European Renewable Energy Network (European Parliament 2012). The study was commissioned by the European Parliament's industry, research and energy committee. Its main objective is not to influence the member states' decision regarding nuclear energy, but to identify the network infrastructure changes necessary to increase the share of renewable energy, including different technologies for storing renewable energy. Provided there is sufficient support, the report predicts wind power could become cost-effective in Europe by the end of the current decade, and solar energy as early as 2015 in Central and Southern Europe.

At the political level, the most important lesson of the European responses to the Fukushima accident lies in the attitude of the leaders with regard to both opposition parties and public opinion. As we have mentioned above, and although several differences occurred, the European media almost unanimously expressed the concerns of public opinion. The reactions of the political leaders proved to have followed, however, totally divergent routes, and the importance given to public opinion and alternative approaches have varied depending on the country.

Last, the diversity of the reactions to the Fukushima accident proved the absence of an automatic and coherent European approach, and confirmed a situation in which, on highly sensitive issues such as energy policies, the positions of the member states still prevail. In that sense, the agreement reached on stress tests and the success of the EU hardly eclipses the divisions at the more important level of decision-making, on what energy policy should look like.

\section{CONCLUSION}

In conclusion, by overcoming a crisis of its energy policy that appeared almost certain in spring 2011, the EU has demonstrated both the independence of its members on nuclear energy issues and its capacity to define a common strategy on important aspects, such as nuclear safety. As long as a general consensus on the direction of EU energy policy prevailed, progress towards such a policy has been impressive and seemed nearly unstoppable. The aftermath of the Fukushima accident had a deep impact on this consensus, but the rational approach of the EU members on nuclear safety had the effect of not jeopardizing the necessity for a common energy policy. The capacity of the EU to address the challenge of a common energy policy, although still in progress, may have a major impact on the future of nuclear energy, not only in Europe, but in the 
rest of the world as well. Author and nuclear expert Mark Hibbs thinks that the response of Japan and a couple of Western European countries may determine the global nuclear energy future (Schuttenheim 2012). In other words, the future of the nuclear renaissance seems to lie in the decisions taken by European countries, and the future of the debates at the EU-level.

We may however raise a few questions that remain unresolved, and that the European political leaders may have to face in the near future:

1) What could be the EU position if more countries decide to follow the German example, consecutively to major political changes (mostly due to the economic and financial crisis)? At what point shall we consider that the nuclear renaissance is openly disputed in Europe?

2) What are the chances for success in Germany's search for renewable energy? And what will be the German position if it does not work as efficiently as planned?

3) How solid is the agreement on stress tests? Are some countries likely to call for a revised agreement, in order to push harder or, on the other side, reduce it?

4) What will be France's position if the Green Party pressures the new Socialist government? And what if a hypothetical referendum or a parliamentary vote confirmed the public's fear, like that of Italy in 1987 and in 2011?

5) More generally, is the divergence on nuclear energy symptomatic of the problems the EU members generally face, or an isolated and specific case?

One may also question the future of the EU's energy policy, not only after important and totally divergent unilateral decisions have been made by its members, but also in regard to the potential orientations it should take. Prior to the Fukushima accident, nuclear energy was clearly identified as a necessary (if not inevitable) option, alongside the development of renewable energy. In May 2010, an EU Commission chaired by Spain's former Prime Minister Felipe Gonzales stated in its conclusion of its reports on the future of the EU that "the search for a more viable energy mix must also involve recourse to nuclear energy. Europe cannot afford to relinquish this important source of power" (Gonzales 2010). Is this reality, confirmed at the highest levels a few months before Fukushima, still valid after the nuclear accident and the spectacular decisions taken by major EU members such as Germany? As two experts from the Brussels-based Centre for European Policy Studies stated, "If European energy policy is to have a meaning in the future, then it will need to address the risk of the cross-border externality of radioactive fallout from a nuclear reactor, including procedures for measures to be taken in the case of an accident and for compensation across borders. Otherwise, clauses on solidarity will sound empty and hinder EU energy policy development" (Egenhofer and Behrens 2011). 
We may also at last question the implications of the EU divergences on nuclear energy for other regions, particularly Northeast Asia. In that sense, it appears that the EU remains a specific case, regarding the possibility for countries that have decided to phase-out to rely on EU partners for energy supplies prior to the reconversion of their energy policies. In this prospect, the example of the France-Germany relation is both particularly relevant and unique, as it embodies a partnership that does not exist in other regions.

The European responses to Fukushima are therefore a unique case of radical transformations in national energy policies, the establishment of a set of measures to increase the nuclear safety, but also the balance of unilateral decisions and a common approach. Overall, this crisis has had the effect of boosting EU capacities to address important challenges such as nuclear safety, and at the same time has not provided significant answers on the question of a common energy policy that includes a more coherent nuclear policy.

\section{REFERENCES}

Bloomberg. 2011. Merkel review shows Fukushima put EU energy targets at risk.

Boyd, Clark. 2011. Europe Reacts to Japan's Nuclear Power Crisis. PRI The World, March 16. http://www.pri.org/stories/science/energy/europe-reacts-tojapan-s-nuclear-power-crisis2942.html.

Brown, Dave. 2011. Europe Reexamining Nuclear Power Policy Landscape. Uranium Investigating News, October 4. http://uraniuminvestingnews.com/ 9294/europe-reexamining-nuclear-power-policy-landscape.html.

Bryant, Lisa. 2011. Europe's Nuclear Debate at forefront after Japan Disaster. The Epoch Times.

Cooke, Stephanie. 2011. After Fukushima, Does Nuclear Power Have a Future?. The New York Times, October 10.

Cravens, Gwyneth. 2007. Power to Save the World: the Truth about Nuclear Energy. New York: Knopf.

Dessus, Benjamin. 2011. Sortir du nucléaire en 20 ans [Phase-out nuclear in 20 years]. Global Chance, June 21. http://www.global-chance.org/IMG/pdf/Sor tirDuNucleaireEn20ans.pdf.

Les Echos. 2011. Nucléaire: Une trentaine de réacteurs dans le monde risquent d'être fermés. [Nuclear: some 30 reactors worldwide may be closed]. April 12.

Economist. 2011a. Nuclear Power? No Thanks (Again).

Economist. 2011b. When the steam clears.

Egenhofer, Christian, and Arno Behrens. 2011. Does Europe Need a Comprehensive Energy Policy? Intereconomics 46(3): 124-28. 
Ergo. 2011. Nuclear Power After Fukushima. European Fallout. August. www. ergo.net/Europe_Nuclear.pdf.

European Climate Foundation. 2010. Roadmap 2050. http://roadmap2050.eu/con tributing_studies.

European Parliament. 2012. European Renewable Energy Network. Directorate-General for Internal Policies, Policy Department, Brussels. January. http://www.europarl. europa.eu/meetdocs/2009_2014/documents/itre/dv/renewable_energy_network_/renewable_energy_network_en.pdf.

Ferguson, Charles D. 2007. Nuclear Energy: Balancing Benefits and Risks. New York: Council on Foreign Relations.

Findlay, Trevor. 2010. The Future of Nuclear Energy to 2030 and its Implications for Safety, Security and Nonproliferation: Overview. The Centre for International Governance Innovation (CIGI): Waterloo, Canada.

Galiay, Artus. 2011. Nuclear Energy in Europe: With or Without You? The New Federalist, October 7. http://www.thenewfederalist.eu/Nuclear-energy-inEurope-with-or-without-you, 04512.

Gonzales Marques, Felipe. 2010. Project Europe 2030. Challenges and Opportunities. Report to the European Council by the reflection group on the future of Europe 2030.

Herbst, Alan M., and George W. Hopley. 2007. Nuclear Energy Now: Why the Time has come for the World's Most Misunderstood Energy Source. New York: Wiley. IISS. 2011.The fallout from Fukushima. IISS Strategic Comment 17.

Le Journal du Dimanche. 2011. Le nucléaire s'invite dans la campagne [Nuclear takes part to the campaign].

Kaljuvee, Ardo. 2010. JUHTKIRI: Tuumaelektri renessanss [Nuclear power renaissance]. Eesti Päevaleht.

Kanter, James. 2011. Switzerland Decides on Nuclear Phase-Out. The New York Times.

Kitschelt, Herbert P. 1986. Political Opportunity and Political Protest: Anti-Nuclear Movements in Four Democracies. British Journal of Political Science 16(1): 57-85.

Lévêque, François. 2012. Is the Nuclear Phase-Out a Financially Viable Option for France?. EU Energy Policy blog, January 18. http://www.energypolicyblog. com/2012/01/18/is-the-nuclear-phase-out-a-financially-viable-option-for-france/.

MacIsaac, Tara. 2011. Nuclear Energy After Fukushima. The Epoch Times.

Manac'h, Erwan. 2011. Accident nucléaire de Fukushima: 'Une catastrophe gravissime' [Fukushima nuclear accident: a major catastrophy]. Politis.

Nodé-Langlois, Fabrice. 2011. Sortir du nucléaire, une idée irréaliste [Nuclear phase-out, a surrealist idea]. Le Figaro.

Novak, Jan A. 2011. Fukušima: hrozí nový Černobyl? [Fukushima: the threat of a new Chernobyl?]. Hospodářské noviny.

Ouest France. 2011. L'arrêt du nucléaire allemand 'favorable' à la France selon Sarkozy [The German nuclear phases-out favorable to France, according to 
Sarkozy]. June 7.

Pidd, Helen. 2011. Germany to shut all nuclear reactors. The Guardian, May 30. http://www.guardian.co.uk/world/2011/may/30/germany-to-shut-nuclearreactors.

Le Parisien. 2011a. Kosciusko-Morizet: 'Accident nucléaire très grave au Japon.' [Kosciusko-Morizet: Very severe nuclear accident in Japan]. March 14.

Le Parisien. 2011b. Anne Lauvergeon: 'Il y a peut-être des leçons à tirer en France' [Anne Lauvergeon: there might be lessons to take in France].

Le Parisien. 2011c. Crise nucléaire au Japon: Paris redoute 'le pire des scénarios' [Japan nuclear crisis: Paris fears 'the worst of the scenarios'].

Reuters. 2011. Analysis: Nuclear renaissance could fizzle after Japan quake.

Richburg, Keith B. 2011. Japan crisis revives global nuclear debate. The Washington Post.

Rizzo, Sergio. 2011. 'il Nucleare e Noi' [The nuclear and us]. Corriere della Sera.

Rüdig, Wolfang, ed. 1990. Anti-Nuclear Movements: A World Survey of Opposition to Nuclear Energy. Detroit, MI: Longman Current Affairs.

Schneider, Mycle, Steve Thomas, Antony Froggatt, and Doug Koplow. 2009. The World Nuclear Industry Status Report. German Federal Ministry of Environment, Nature Conservation and Reactor Safety. Berlin.

Schneider, Mycle. 2011. Fukushima Crisis: Can Japan be at the Forefront of an Authentic Paradigm Shift?. Bulletin of the Atomic Scientists, September 9. http://www.thebulletin.org/web-edition/features/fukushima-crisis-can-japanbe-the-forefront-of-authentic-paradigm-shift.

Schuttenheim, Rolf. 2012. Nuclear Future on Balance: World Has Not Responded to Fukushima, Europe Has. Bits of Science, January 7. http://www.bitsofscience.org/fukushima-nuclear-energy-europe-4642/.

Sokolski, Henry. 2011. Nuclear Power Goes Rogue. Newsweek.

Der Spiegel. 2011. Fukushima Marks the End of the Nuclear Era.

De Standaard. 2011. Debat over kernenergie laait opnieuw op [Debate on nuclear energy flares again].

Der Standard. 2011. Faymann und Berlakovich betreiben 'verlogene' Atompolitik [Faymann and Berlakovich 'hypocritical' nuclear policy].

UFE. 2011. Electricité 2030. Quels choix pour la France [Electricity 2030. What choices for France]. Union Française de l'Electricité. http://www.ufe-electricite.fr/IMG/pdf/brochure_synthese_ufe_fr_bd.pdf.

L'usine nouvelle. 2011. Nucléaire: José Manuel Barroso plaide pour une prise en compte des risques humains [Nuclear: José Manuel Barroso advocates a consideration of human risks]. May 11. http://www.usinenouvelle.com/article/nucleaire-jose-manuel-barroso-plaide-pour-une-prise-en-compte-des-risqueshumains. N151673.

Voskimovich, Vojin. 2012. Fukushima Nuclear Accident, the Media and Internat- 
ional Responses. Modern Tokyo Times.

Die Welt. 2011. Hubschrauber werfen Wasser über Atom-Reaktor ab [Helicopter takes off over water nuclear reactor].

World Nuclear Association. 2011. Policy Responses to the Fukushima Accident. World Nuclear Association. 